\title{
組織反射スペクトル解析による動注動態の検討
}

\author{
宮崎医大整形外科 \\ 田島 直也・木 村 千 仍 \\ 宮崎・串間病院 \\ 永 吉 康 祐 \\ 久留米大学第二内科 \\ 下津浦 康 裕・佐 田 道 夫
}

\section{Study of Reflectance Spectrophotometric Analysis on Intraarterial Injection}

by

\author{
Naoya Tajima and Chihiro Kimura \\ Department of Orthopedic Surgery, \\ Miyazaki Medical College, Japan \\ Kohyu Nagayoshi \\ Kushima Hospital, Miyazaki, Japan \\ Yasuhiro Shimozuura and Michio Sata \\ Kurume University, Kurume, Japan
}

\begin{abstract}
Hemoperfusion and oxygen saturation were investigated by tissue reflection spectra in forty-one cases with rheumatoid arthritis and osteo-arthritis who received intraarterial injection. Forty-one cases were classified into three groups based on the method of intraarterial injection; $20 \mathrm{ml}$ of $20 \%$ glucose and active $\mathrm{VB}_{1}(10 \mathrm{mg})$ through the femoral artery (Group A), and cubital artery (Group B), and $20 \mathrm{ml}$ of physiological saline solution and active $\mathrm{VB}_{1}(10 \mathrm{mg})$ through the femoral artery (Group C). It has been confirmed that initial I- $\mathrm{SO}_{2}$ (Index of $\mathrm{SO}_{2}$ ) of Group B is more than 2 times as high as those of Group A and Group $\mathrm{C}(\mathrm{P}<0.001)$, and that the local $\mathrm{Hb}$ oxygen saturation is higher in the upper limbs. Initial values of $\mathrm{I}-\mathrm{Hb}$ (Index of $\mathrm{Hb}$ ) obtained before the intraarterial injection in Group $\mathrm{B}$, Group $\mathrm{A}$ and Group $\mathrm{C}$ are high in this order, but the difference in values between Groups B, A and $\mathrm{C}$ is not so great as that in $\mathrm{I}-\mathrm{SO}_{2}$ values.
\end{abstract}

\section{はじめに}

四肢の炎症性疾患，RA などに対し，1942 年中山ら はブドウ糖を用いて Intraarterial injection therapy を 発表し, その作用機序として白血球, 組織球の細菌貧 食度の妄進や, 薬理的特性, 渗透圧による物理的作用 などをあげている。

私達は Intraarterial injection therapy の臨床結果 についてはすでに第 57 回日整会において報告したが, その生理的効果の解明の 1 つとして, Intraarterial injection 前後における下肢の $\mathrm{Hb}$ 量（血流量）酸素飽
和度の動態につき検討したので報告する。

対

象

Intraarterial injection therapy を行った主にOA, $\mathrm{RA}$ など 41 例を intraarterial injection の方法により， 次の 3 群に分けた。

A 群 21 例：20\% glucose $20 \mathrm{ml}$ と活性 $\mathrm{VB}_{1}$ を股動 脈に行ったもの（35〜 76才，平均 60 才）

B群 11 例： $20 \%$ glucose $20 \mathrm{ml}$ と活性 $\mathrm{VB}_{1} 10 \mathrm{mg}$ を肘動脈に行ったもの $(30 〜 78$ 才，平均 51 才）

$\mathrm{C}$ 群 9 例 : $\mathrm{NaCl}$ (生食) $20 \mathrm{ml}$ と活性 $\mathrm{VB}_{1}$ を股動脈 


\section{に行ったもの（41〜 76 才，平均 58 才）}

\section{測定法}

測定は組織スペクトル分析装置「Ts-200」(住友電工, 日本）を使用した。これは光ファイバー束のプローブ を組織にあて白色光を照射し，反射光より組織の吸収 スペクトル分析を行い, 組織内色素の動態を経時的, 定量的に computer で連続スペクトルを算出描出出来 るものであり，標準白色板の反射スペクトルと測定対 象の反射スペクトルの対数の差が吸収スペクトルとし て算出される ${ }^{3)}$.プローブは貼付用を用い, 測定部位は 下腿下 $1 / 3$ 外側または，前腕橈側末梢部で経皮的に測 定した。

測定值は吸収波長を反映するパラメーターとして算 出され, I HB (Index of $\mathrm{Hb}$ ) は 0 〜200 迄变化する 指数であり, $\mathrm{I} \mathrm{SO}_{2}$ (Index of $\mathrm{SO}_{2}$ ) は $0 \sim 100$ 迄変化 する指数である。(動脈血で $\mathrm{PO}_{2}$ と相関をとると, I $\mathrm{SO}_{2} \times 1.333$ の值とほぼ一致する).

\section{結果}

$\mathrm{A} \sim \mathrm{C}$ 群につき Index of $\mathrm{SO}_{2}\left(\mathrm{I} \mathrm{SO}_{2}\right)$ と Index of $\mathrm{Hb}(\mathrm{I} \mathrm{Hb})$ を $1 / 2$ 秒每に算出し，動注時と Max 值（動 注後)，動注開始時から Max 迄の時間を読みとった。

\section{(表参)}

$\mathrm{I} \mathrm{SO}_{2}$ について

A (20\% G，下肢)，C ( $\mathrm{NaCl}$ 下肢) に比し， B ( 20 $\% \mathrm{G}$, 上肢)の方が initial の $\mathrm{SO}_{2}$ が 2 倍以上高く $(\mathrm{P}<$ $0.001)$, 上肢の方が局所の $\mathrm{Hb}$ の酸素飽和度が高いこと が確認できた。また Max 值では B (上肢)，A (下肢)， $\mathrm{C}$ (下肢) の順であり，B，Aはかなり上昇するが，

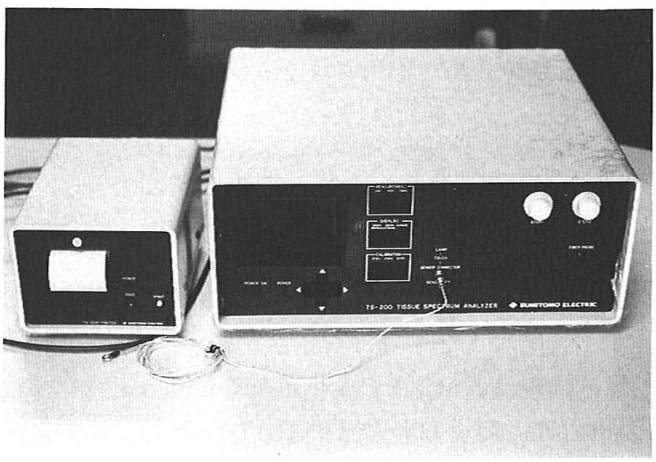

図 1 組織スペクトル分析装置（TS-200）

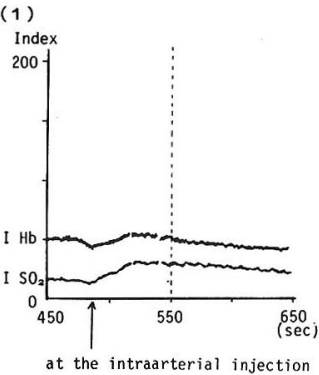

(1) Trend record monitarring

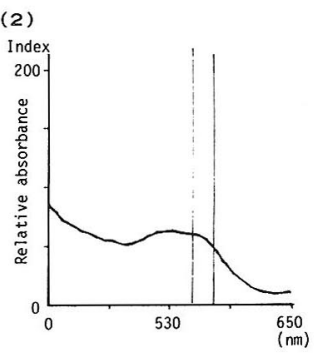

(2) Reflectance spectra

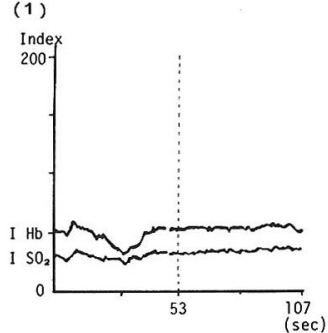

(1) Trend record monitar ring

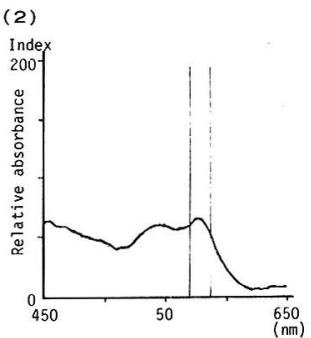

(2) Reflectance spectra

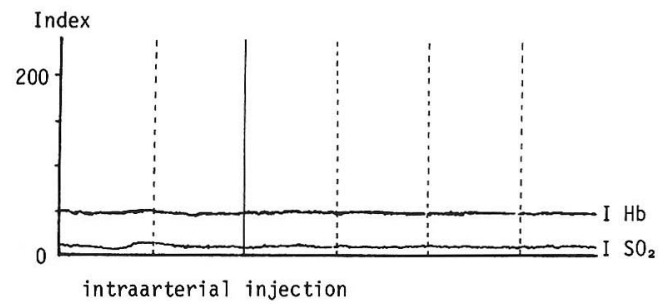

Trend record moniaring

Group C (Case S.H., 58y, Male)

図 2 A. B. C. 群代表例の酸素飽和度, $\mathrm{Hb}$ 量の終時的 変化 (上, 中の右はスペクトルパターン)

C $(\mathrm{NaCl})$ の上昇は少く, Glucose と $\mathrm{NaCl}$ の作用の 差が明確に出たものと考元られる.Max 迄の time は 上昇した A B で $50 \mathrm{sec}$ 前後であり, 反応は injection 後 しばらく経過しておこることが示唆された。

I $\mathrm{Hb}$ につて

I $\mathrm{Hb}$ の動注前の initial の值は, B (上肢), A (下 肢), $\mathrm{C}$ (下肢) の順で上肢の方が高かったが， $\mathrm{I} \mathrm{SO}_{2}$ の值ほど，Bは A，Cに比し高くなかった。これも上 肢と下肢の血行の特殊性と考えられる。 
表 1 酸素飽和度指数, $\mathrm{Hb}$ 量指数の $\mathrm{A}, \mathrm{B}, \mathrm{C}$ 群別 の結果

Index of $\mathrm{SO}_{2}$

\begin{tabular}{|c|c|c|c|c|}
\hline & Init & $\operatorname{Max}$ & $\begin{array}{c}\text { Max迄のtime } \\
(\mathrm{sec})\end{array}$ & up 率 \\
\hline $\begin{array}{l}\text { A 群 } \\
\text { B群 } \\
\text { C 群 } \\
\text { Sig. } \\
\text { dif. }\end{array}$ & $\begin{array}{r}12.5 \pm 5.6 \\
27.6 \pm 8.9 \\
11.7 \pm 3.8 \\
\left(\begin{array}{l}\text { A B } \\
\text { B C }\end{array}\right. \\
(\text { up 率 }=\text { M }\end{array}$ & $\begin{array}{l}24.4 \pm 5.2 \\
40.9 \pm 8.2 \\
16.1 \pm 4.1 \\
\text { (A B, A C } \\
\text { B C } \\
\text { ax値一注入時 } \\
\text { 注入時値 }\end{array}$ & $\begin{array}{c}52.3 \pm 26.8 \\
47.7 \pm 38.2 \\
26.9 \pm 22.5 \\
\text { A C } \\
\text { 值 } \\
\times 100(\%))\end{array}$ & $\begin{array}{r}121.7 \\
61.3 \\
46.1\end{array}$ \\
\hline \multicolumn{5}{|c|}{ Index of $\mathrm{Hb}$} \\
\hline & Init & $\operatorname{Max}$ & $\begin{array}{c}\text { Max迄の time } \\
(\mathrm{sec})\end{array}$ & up 率 \\
\hline $\begin{array}{l}\text { A 群 } \\
\text { B群 } \\
\text { C 群 } \\
\text { Sig. } \\
\text { dif. }\end{array}$ & $\begin{array}{c}39.2 \pm 11.6 \\
45.5 \pm 12.8 \\
29.8 \pm 11.2 \\
\left(\begin{array}{l}\mathrm{B} \mathrm{C} \\
\mathrm{AC}\end{array}\right. \\
\text { up 率 }=\end{array}$ & $\begin{array}{c}44.0 \pm 11.5 \\
59.4 \pm 9.6 \\
32.7 \pm 10.8 \\
\left(\begin{array}{l}\text { A B } \\
\text { A C } \\
\text { B C }\end{array}\right. \\
\text { 值－注入時 } \\
\text { 注入時值 }\end{array}$ & $\begin{array}{r}45.6 \pm 19.8 \\
41.9 \pm 23.8 \\
48.9 \pm 48.5 \\
\\
\text { :值 } \times 100(\%))\end{array}$ & $\begin{array}{l}14.3 \\
38.7 \\
11.3\end{array}$ \\
\hline
\end{tabular}

Max の值 (動注後) も B, A, Cの順であるが, $\mathrm{I} \mathrm{SO}_{2}$ より上昇が少く, up 率で Bが高いのは上肢と下肢の volumeの差と考えられる.

Max 迄の time, AB, Cいづれも $40 \mathrm{sec}$ 以上かかり, 毛細血管迄の影響はかなりたってからでないと表われ ないことを示している.

以上より,概して $\mathrm{Hb}$ の up より $\mathrm{SO}_{2}$ の up が高いと いえる。

\section{考察}

動注療法は 1942 年中山ら ${ }^{5)}$ が発表して以来, 一時的 には広く普及したが, 最近はあまり用いられていない。 これは，手技にやや困難性があるためと思われるが， 今回の測定からは,作用は $\mathrm{NaCl}$ では変化がないことよ り glucose 特有のものであり, また血流より $\mathrm{I} \mathrm{SO}_{2}$ (酸 素飽和度）の方が変化がおこることが判明した。

一般的に皮膚を表面から圧迫すれば血管内の血流が 駆遂され, IHb は低下し,さらに続く数秒後, 組織が $\mathrm{Hb}$ の酸素を奪い,酸化 $\mathrm{Hb}$ から還元 $\mathrm{Hb}$ への変換が進 行し， $\mathrm{I} \mathrm{SO}_{2}$ が低下する。

動注時の $\mathrm{I} \mathrm{SO}_{2}$ 酸素飽和度は注入開始から, $\max$ 迄 の時間は平均 40〜 $50 \mathrm{sec}$ であり, 物理的に動注の血流
変化の後,引き続きおこった 2 次的変化と考えられる. 一方 $\mathrm{Hb}$ 量 (血流量) の方は動注後若干増加はするが, I $\mathrm{SO}_{2}$ の変化ほど上昇しない.

結果的には組織の酸素の需要より供給が大で, 酸化 $\mathrm{Hb}$ から還元 $\mathrm{Hb}$ への変換が小さいのと血流量の増大が 原因と考えられる。

しかし，この $\mathrm{Hb}$ 量, $\mathrm{I} \mathrm{SO}_{2}$ の変化は一時的であり， また元にもどっているが, 臨床的には pain の寛解, 抗 炎症作用が数日続く例がみられる。

これは glucose により惹起された末梢神経終末作用 物質, 抗炎症作用の反映とも考元られ, 興味深い.

反射スペクトルの解析は生体色素として $\mathrm{Hb}$ がもっと も関与し,スペクトル強度は,ほとんどは血液の $\mathrm{Hb}$ に 関係し，スペクトルパターンは酸化，還元の程度を示 すと考えられる。

$\mathrm{SO}_{2}$ は全 $\mathrm{Hb}$ 中の酸化 $\mathrm{Hb}$ の割り合いを示し,酸素飽 和度と呼ばれるパラメーターで $\mathrm{SO}_{2}$ が変化するとスぺ クトルパターンが変化する。本装置では $\mathrm{SO}_{2}$ によりス ペクトル值が変化しない波長域（650 mm 附近）を利用 して $\mathrm{SO}_{2}$ を示すパラメーターと $\mathrm{Hb}$ 量を示すパラメー ターが算出されている。

前田ら ${ }^{4)}$ は測定深度の検討で皮膚表面からは $0.3 \sim 0.4 \mathrm{~mm}$ 附近の真皮残局部の毛細血管蹄の存在す る部位が得られると述べている。

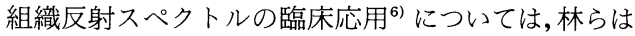
慢性肝疾患 ${ }^{2)}$ に対し, 肝血流と酸素消費の検索に, 需石 らは歯周疾患の診断に応用出来ることを発表してい $3^{188}$. この他内視鏡 ${ }^{7}$ と併用し, 局所血行動態の検索に 応用されつつある。しかし，内視鏡と共に用いる時は プローブの圧迫程度が微妙に影響する。

いづれにしろ組織反射スペクトル解析は微細な変化 もとらえられ, micro circulation の解明に有効な手段 で，今後臨床上広く応用されうる検査方法であると考 えられる。

\section{ま と め}

1. Intraarterial injection の作用機序, 生理的効果 の 1 つとして injection 前後の $\mathrm{Hb}$ 量, 酸素飽和度の動 態につき検討した。

2. 作用は $\mathrm{NaCl}$ では変化がなくGlucose 特有であ り血流 ( $\mathrm{Hb}$ 量) より酸素飽和度の方に変化がみられた。

3. 組織反射スペクトル解析は微細な変化もとらえ られ， microcirculation の解明に有効な方法と考えら 
れた。

(御協力頂いた久留米大第二内科, 下津浦, 佐田先生に感謝 致します.)

\section{参 考 文 献}

1）埴岡 隆：反射スペクトル解析法の歯周疾患への臨 床応用一歯肉の局所血流量ならびに酸素利用能の検 討一口腔衛生学雑誌。33：99-100, 1983.

2）林 紀夫：臓器反射スペクトル解析による慢性肝疾 患者肝の局所循環動態と酸素代謝動態の検討。日内会 誌, 68：1554-1561, 1979.

3）平本順一, 神田昌彦: 医療用組織スペクトル分析装 置.レーザー研究, $13 ： 165-170,1985$.
4) 前田 求：組織反射スペクトル解析による皮膚血行 動態測定法の検討. 皮膚, $26: 66-73,1984$.

5）中山恒明：動脈性衝撃注射療法。東京・中央, 協同 醫書出版社, 東京 1948 .

6) 佐藤信紘・他：臓器反射スペクトル解析による藏器 の機能診断. 医用電子と生体工学, $17: 66-72,1979$.

7）佐藤信紘・他：加令と胃粘膜血流動態一内視鏡下で の高速・連続的藏器反射スペクトル法による測定. 日 本消化器病学会誌, 78:2074-2077, 1981.

8）零石 聰, 埴岡 隆・他：反射スペクトル解析法の 歯周疾患への臨床応用. 歯界展望, $63: 345-352,1984$.

9) Tajima $N$. et al. : Intraarterial Injection Therapy for Relief of Severe Pain (Preliminary Report). Jpn. J Rheum. Joint Surg., (3) : 245-251, 1985. 